Eva Hideg, Erzsébet Nováky and Péter Alács:

\title{
Interactive foresight on the Hungarian SMEs
}

The paper was Published in Foresight, 2014, 16, 4, pp. 344-359.

Permanent link to this document:

http://dx.doi.org/10.1108/FS-12-2012-0091

\begin{abstract}
Purpose - The aim of this study is to present a concept of interactive foresight process, its theoretical and methodological considerations and a foresight exercise concerning the development of knowledge economy in the Central Hungarian Region.

Design/methodology/approach - A methodology of interactive foresight process for creating regional future concepts is developed, which is based on a specific meaning of integral futures and uses online solutions, too.

Findings - Personal meetings with small and medium enterprise (SME) stakeholders and the works of interactive communications with feedbacks within and among stakeholder groups was organized around the research homepage. The networking created the interconnection and the feedbacks between the stakeholders and the futurist group in the process of shaping regional future ideas. The online networking is running.

Research limitations/implications - The low number of stakeholders can limit the validity and acceptance of futures ideas created by this process.

Practical implications - The developed interactive foresight process can also be applicable at different organizational levels and in different fields for shaping shared future ideas.

Social implications - Application of interactive foresight process can contribute to the development of anticipatory democracy.

Originality/value - A theoretically based interactive foresight process has been developed in which stakeholders can participate not only interactively in the foresight process but they can implement the achievements in their enterprising activity as well. The participants were interested in foresight and cooperative during the whole process because they learned the use of foresight tools through collective solution of practical tasks which were important for them.
\end{abstract}

Keywords Foresight, Forecasting, Research methods, Scenario planning, Knowledge creation, Regional development

Paper type Research paper

\section{Introduction}

Foresight processes are applied very often in the futures fields to shape futures ideas concerning certain fields of reality with the participation of futurists, experts and/or stakeholders and lay people. Different processes are used depending on the aims, the subjects and the tasks of foresight as well as the needs of customers. We agree with the statement that basically there are two different kinds of foresight meanings at present (Hideg, 2007). One of them is the foresight in futures studies which emphasizes the development of future intelligence or future literacy of participants (Slaughter, 1995, 2004, 2008; Hideg and Nováky, 1998; Hideg et al., 2013; Inayatullah, 2006; Stevenson, 2006; Miller, 2007). The other one is the praxis foresight which is developed to support decision making focusing mainly on providing future-oriented recommendations to policy makers and business men (Miles, 2008; Havas et al., 2010; European Foresight Monitoring Network, 2011).

Studying foresight issues we have found two main problems. The first problem is that the relationship of foresight activities to the futures theories is not well-explained. Although Fuller and Loogma (Fuller and Loogma, 2009) placed foresight methodologies into the social 
constructivist perspective, their explanations merely give general philosophical backgrounds for foresight activities. On the other hand, no well-underpinned explanation has been given why more subjective or inter-subjective future concepts cannot be feasible in practice even if they represent consensus with regard to futures ideas and among participants, together with being transparent and legitimate. We think that the latter question is also worth to be reconsidered and can be answered better by using the co-evolutionary perspective.

The other main problem concerning foresight is the lack of interconnections among different phases of foresight within the foresight process on the one hand and between foresight and practical actions based on the futures ideas, concepts that were developed during a foresight process on the other hand. Recently, Hines and Bishop (Hines and Bishop, 2006) edited a detailed and comprehensive guideline to carry out a methodologically well-based foresight activity. Following phases of a foresight process as framing, scanning, forecasting, visioning, planning and acting, the authors presented methodological solutions for tasks arising in each phase of a foresight process; however, they did not deal with problems of interconnections and feedbacks among the phases. Therefore we aim to take the first step toward this direction by introducing the idea and a methodological solution of interactive foresight. Contributing to the aforementioned two foresight issues we designed an interactive

foresight process. The purpose of this study is to present this interactive foresight concept and process, its theoretical and methodological considerations and an interactive foresight case study concerning the development of future concepts toward the knowledge-based economy in the Central Hungarian Region (CHR).

\section{Theoretical and methodological considerations}

Interactive foresight is a kind of scientifically based practical foresight activity that updates the practice of participatory futures based on the theoretical considerations of co-evolutionary paradigm of integral futures (Hideg, 2013). The idea of integral futures was first shaped by R. Slaughter. His concept of integral futures means the further development of critical futures in which different kinds of knowledge integration could be achieved by

development of personal intelligence of participants (Slaughter, 2008). We agree with Slaughter from that point of view that the development of personality is also carried out in an integral futures activity, but shared and socially accepted futures ideas which are underpinned by scientific and experimental approaches and knowledge and emerged by interactions among different creative participants also have to be shaped in parallel with it.

Without the latter, the integral futures cannot be interpreted. Therefore we differentiate between the integral futures as a scientific field and the complex future ideas about certain fields of reality that are the results of participatory foresight activities (Hideg, 2013).

According to our concept, the theoretical integral futures could comply with the coevolutionary paradigm. It means that the theoretical integral futures should be focused on the subject domain of futures and give interpretation and methodological consideration of future as multiple development paths of open and co-evolutionarily changing complex systems. The co-evolutionary interpretation of system changing supposes that complex system is working in mutual interaction with its environment that consists of other complex and evolving systems. Complex system that can be subject domain of futures includes activity and future ideas of human agency as a component system that also interacts within the complex system that is under discussion. This interpretation or comprehension of future makes possible to compose a research perspective in which integration of knowledge acquisition or different kinds of knowledge about society can take place on the basis of complex system dynamics. 
The other field of integral futures could be the integral foresight practice because the subject domain of futures contains activity and future ideas of human agency as a praxis that can be influenced by "artificially established and organized" foresight practice (based on results of theoretical integral futures among them). The mission of integral foresight practice is to solve this knowledge acquisition and integration with the help of the aforementioned theoretical framework and involving of a wide range of different stakeholders' activities, too (Hideg, 2009). It has only a process-type paradigm whose basic characteristic is participation. Both fields of integral futures can work relative separately, but in an interactive way according to our conception.

Following this concept of integral futures the ideas about the futures are formed out in the actual present time and concern the possible, acceptable/desirable and feasible interactions within the human system and between human system and its environment. Future ideas about certain fields represent multiple constructions of mental, reasonable and scientifically based thoughts reflecting on the changing outer environment, the inner social affairs and personality that are continuously being born in the sphere of human world together with influencing and shaping co-evolutionary processes among personalities, societies and non-human worlds by human interactions. These future ideas really contain scientific, experimental thoughts and expectations, desires even if they are shaped by scientifically based foresight processes; thus they are different from the concept of integral futures as a scientific field. The mission of theoretical futures within integral futures is to develop the meaning of co-evolutionarily shaped futures, the role of human agency in them, in addition to the methodology and methods for practical foresight activity. We think that the co-evolutionary perspective provides more suitable and useful basis for foresight methodologies than the social constructivist one (Fuller and Loogma, 2009). The co-evolutionary perspective makes it possible to pay attention to real or evolutionary limits, precaution and innovation so that it can help not to construct anything collectively that we only want concerning the future.

On the other hand, the possible, acceptable/desirable and feasible future ideas are to be developed in the practice and with the participation of future-shaping stakeholders through integral foresight processes carried out in different time and place and about different fields. The development of these practical futures activities should be carried out by widening and improving processes and methods of participatory foresight in the course of solving palpable tasks determined by the needs of actual practice (Nováky, 2011). This concept of integral futures can also give the possibility to bridge the gap between theoretical and practical concerns in the field of futures studies and foresight (Hideg, 2007).

It is needed to be remarked that the phrase of integral foresight can also be found in the literature of praxis foresight. The integral character of foresight is interpreted as an integral element of networked and distributed policy making by its policy informing, facilitating and advisory functions (Miles, 2008; Da Costa et al., 2008; Eriksson and Weber, 2008). In another interpretation, the technology foresight makes effort to involve itself into the economic and social issues associated with technology development and the democratic civil society as participants (Georghiou, 2001; Havas, 2011, Hronszky and Fésüs, 2011). Saritas has introduced the idea of systemic foresight and outlined its methodology (Saritas, 2011). It seems to us that we go on different paths but toward almost the same purpose. In the development of a foresight process for shaping of future ideas concerning economy of CHR, we undertook to improve the anticipatory democracy, the future-knowledge base 
of national individual stakeholders and their groups interconnectedly and the exploration of regional future ideas based on knowledge, experience and creativity of active, reflective and responsible participators.

We consider the improvement of anticipatory democracy (Toffler, 1970; Bezold, 2008) to be important assuming that the main resource of economic development in CHR is the welleducated and trained citizens as entrepreneurs and employees. Based on statistical data of wide range and scientific expert studies in our analyses, the CHR is not only the most developed region having a service economy but also it is a research, educational, training and innovation center in Hungary. Human resources embodied in knowledge and culture can only be employed to serve economic development if people and their economic organizations are capable of shaping their futures consciously. The anticipatory democracy does not mean the expansion of dreams, utopia or anti-utopia of the laity, but it means the reflective and conscious experience of citizens' participatory positions in the regional economic processes and their changes (Leydesdorff, 2001). Anticipatory democracy supposes and contains knowledge of scientific experts and professionals both about natural, social and economic situation and their developmental possibilities and limits of the region and collective shaping of regional futures, at the same time. Communicative interactivity of two kinds of knowledge can only result in scientifically based, transparent and feasible future ideas which can be accepted by participants as well as encourage further activities and collaboration of participants.

\section{Exploration of regional future ideas based on the knowledge, experience and creativity of} active, reflective and responsible participants is highly important because these future ideas can form the expectations of regional economic actors so that they will be encouraged to work out innovative business solutions and developmental tasks and to develop their foresights to respond to changing circumstances. If the actors and stakeholders experience the advantages of the active, reflective, responsible and participatory future shaping through interactive foresight activity, then interactive foresight can become organic part of everyday business activities.

The interactive foresight is not only a special kind of participative integral foresight exercise but can also be interpreted as a specific alloy of open foresight, open innovation and the possibilities of using info- ommunicational technology (ICT). Open foresight enables such a kind of foresight process in which participants take part voluntarily and they run on open dialogue aspiring to understand each other and getting to the meaning of their own and the common possible futures (Daheim and Uerz, 2006). Maintaining the concept of open foresight we also consider important to involve the scientific and expert knowledge in the foresight process that is to open in the respect of other knowledge resources of foresight, too. Exploiting the concept of open innovation (Chesbrough, 2003; Hippel, 2005) we used the idea that new practical knowledge, products, services, processes and technologies are produced on the needs of consumers, and they are born in their social, organizational, cultural and human contexts through open innovation. Therefore, the interactive foresight can be an innovation process that conforms to the needs of consumers during the process of new future knowledge production on one hand, and this new future knowledge is produced by and for the foresight participants and users on the other hand.

Furthermore, the interactive foresight can be interpreted as a special kind of innovation. It is a social innovation[1] that is on the way to becoming a new social technology. This can be applied in policy making at the governance level or in strategy making at the firm level or in 
development of future orientation of citizens and their communities at the micro/meso/ macro social level. For example, in countries where technology foresight has yet been institutionalized, its organizations have become a part of technology governance (Grunwald, 2011). Other type of foresight activities can also get their institutional realization in the near future.

$I C T$ gives possibility to use and analyze information base of different kinds at a wide range and to carry on open communicative interactivity independently of space and time. Thus, our interactive foresight is working on an interactive Web site through which every inquirer can participate in the dialogue on the future of the economy in the CHR, in the application of partial results and the accumulated knowledge. Composing and publishing own future topics and ideas on this Web site participants can contribute to the shaping of regional future thoughts and concepts. Therefore the interactive foresight provides an innovation process of futures knowledge production and futures service that is working as a network of futurists, scientific and practical experts, stakeholders, voluntary participants and other inquirers. It is an experimental means to renew the national futures practice. It can be ranked among the innovation process of Living Labs[2] type.

In the framework of our interactive foresight, the concept of stakeholders' scenario-building (Kok et al., 2006) was adapted and an online research homepage was developed where questionnaires and a jigsaw puzzle[3] were designed and placed. They are accessible for the visitors after signing in and are analyzed periodically. For the visitors, it is also possible to make comments and take part in the dialogue about the regional economic futures and the role of small and medium enterprises (SMEs) in them. Above them a content-mining process of the Hungarian language was developed to accelerate the processing of online documents connecting to our research topics.

The central figures of our foresight process were the stakeholders, who have the determining role in elaborating the practical subject of foresight, and they are the users who will apply the results of foresight and the skills they learn during participation. As our foresight is open, the range of stakeholders could be the entrepreneurs, the representatives of SMEs in the CHR, their employees, the representatives of research organization and higher education, different business federations, civil societies, governmental organizations and the experts in topics of SMEs. We have given priority to the SMEs in the CHR because 99.8 per cent of enterprises are SMEs in this region (Statisztikai tükör, 2009, p. 1), and the enterprises having capability and agility to produce new and "fit for life" innovations continuously could be among them. We tried to involve a wide range of entrepreneurs from the SME sector in our foresight process because 80 per cent of the SMEs in the region have Internet and e-mail access. We asked about 1,000 SMEs - that was a 2 per cent representative sample of SMEs on sub-region level - through e-mail to answer an online questionnaire and to take part in an online discourse on the economic futures of SMEs in CHR. Surprisingly, the response rate was only 1 per cent and only a few of them wrote comments on our homepage. It is very low compared to both our earlier foresight activities and respondent activities in other European foresight programs[4].

After that we involved only a small group of stakeholders that were mainly students in the economic program at the Corvinus University of Budapest who took part in the futures courses, and they and/or their parents had their own enterprise, who were working at SMEs as an employee or a junior clerk, and who wanted to establish an SME or to work at the SME sector in the $\mathrm{CHR}$ in the future. (The total number of participants was 82 persons, among 
them 62 students also took part in every face-to-face workshops.)

Personal meetings with stakeholders and the works of interactive communications with feedbacks within and/or among stakeholder groups represented one aspect of our foresight works that included the training of stakeholders, the future-searching conference, the making of futures wheels and the stakeholders' scenario-building and their discussions and assessments. The other aspect of our foresight work was organized around our research homepage named Future SME - Futures Me (http://futuresme.hu)[5] that included the completion of the stakeholders' questionnaire (only for enterprisers), the participation in a puzzle game (for all participants), the commenting and the studying of documents that were partly the results of this foresight exercise and that were partly recommended by links. Watching our homepage by participants/visitors, their activities on it and the activities of futurist group for strengthening the networking of participants made possible the interconnection and feedbacks between the two aspects of our foresight work. Scenarios of the futurist group based on the results of their research works paying attention to the stakeholders' scenarios have emerged from the synthesis of the partial interactive foresight results. After that the futurist group's scenarios were inserted into the social scenarios for "Hungary 2025" which were products of an academic research (Nováky, 2010b). Social future concepts of "Hungary 2025" were considered as the wider possible future social environment of the function and development of CHR. The economic future concepts on the $\mathrm{CHR}$ and the social future images of Hungary can be connected with each other because both of them were made using participatory process and by participation of young generations as main stakeholders.

In the case of interactive foresight, the tasks of futurist group have multiple characters and have also new characters in more concerns. On the one hand, the futurists had to choose the stakeholders and to make them active, and on the other hand, futurists have had to plan the whole process connecting the aim, subject and tasks of foresight work to each other. Planning of the whole foresight process is directed to the stakeholders' network to be built up and operated. Futurists took part in the operation of the network as facilitators, they prepared, analyzed and made feedbacks of the results in certain phases of the foresight work, and, finally, they summarized the future ideas and concepts of stakeholders and arranged them in structure for the networkers and the public[6].

This interactive foresight program consisted of four phases. In the first phase, the participants were introduced into futures studies, the use of foresight tools applied in this procedure and gained insight into the situation and development problems of the CHR by listening to experts' presentations, using the materials and links on the research homepage, gathering and processing different information, solving the online jigsaw puzzle and filling the online questionnaire. In the second phase, the groups of participants made futures wheels and built up scenarios. In the third phase, they took part in face-to-face and online workshops discussing and evaluating the scenarios. In the fourth phase, the evaluation and categorization of regional economic scenarios and their entrenchment into the social futures concepts of "Hungary 2025" happened. The achievements of foresight program are embodied in future images about CHR at the level of each participants and in accepted common future images about CHR that represent all participants' visions at the foresight group level.

The interactivity in the form of face-to-face and online connections was present in every 
phase of foresight and among the certain phases, too. The interactivity among phases took place in feedbacks of new achievements gained in the latter phase into the early phases to review the previous solutions and to resolve the online jigsaw puzzle. There was also another concern of interactivity in this foresight exercise. Namely, the participants and their groups and the futurist group worked together in a network system way.

In selecting methods, the main point of view was that methods can be used interactively or they can be made interactive by some modification. We think that interactive or interactively used methods are suitable for knowledge integration concerning the actual subject domain. Beyond it the methods chosen make possible to product future information of different types concerning subject domain and its environment in our foresight exercise (Popper, 2008). Literature review was applied and spread among participants so that they could get information from scientific and experts' analyses and other forecasting and foresight exercises. After that interactively created futures wheels and scenarios were developed, and futures workshops were held for different purposes, then evaluation and comparative analysis of scenarios of different types were carried out for emerging and gathering participants' future knowledge. Applying these methods it was made possible that the participants could work together and learn with each other in face-to-face and/or online way. Above them an online jigsaw puzzle was composed to develop creativity of participants and to measure the change in their future orientation. In the game, it was also made possible that the players got to know the summarized result and the relative state of their solutions in the common result immediately after finishing their game.

The whole process itself was well underpinned with scientific results and mostly on integral and participatory futures, but results - future ideas and concepts to shape certain sphere of reality - from this foresight process contained not only scientific components but the developing subjective future thoughts and expectations of stakeholders as well. Due to the latter cause, the interactive foresight can only be regarded as right and reliable, if it mirrors its scientific concerns, legitimate and transparent, and if it can be further developed in the light of actions, events and changing future thoughts of stakeholders. We think that our foresight exercise meets these requirements.

\section{Emerging visions of SMEs in the CHR}

\subsection{About CHR}

CHR is the most developed region in Hungary. Its economy is driven by services, and it has a well-extended infrastructure. One-third of the Hungarian population (about 3 million people) lives in this region. The region has highly educated, well-qualified population, so it is the center of the Hungarian R\&D\&I capacity. Thus $C H R$ attracts international investment and multinational companies. Besides advantages, the region has some disadvantages as well. The level of development is very different within the region. Meanwhile, Budapest, the capital of Hungary, and its agglomeration, is the most developed part in the region, the other territories are underdeveloped at different measures. Many SMEs, but only a few big enterprises, operate in $C H R$. Despite the relatively good results in $R \& D$, the level of innovation activities is moderate in the region.

The Central Hungarian Innovation Center (CHIC) study (CHIC, 2004), the only expert study on the futures of economy in the CHR from 2004, presents one sole possible and desirable 
future for the region. Also considered to be feasible in 2004, the CHR as the integrator of domestic R\&D\&I opens space to the SMEs of the region to bridge R\&D capacities and business activities. The approach to the development focused basically on the way to utilize the facilities of the region. The EU was also a supportive environment in that vision. As the study was written entirely by experts and it was based on the SWOT analysis, the discovered regional advantages and disadvantages were simply used as if they had represented the future development opportunities and boundaries of the region. Time has proven neither the vision nor the approach of the methodology. Amid circumstances of economic crisis it is reasonable to reconsider the regional future concept, as well.

Living, working and researching in this region, we were eager to know in what ways the most popular economic units, the SMEs in the region were thinking of their and the region's economy. Our hypothesis was that persons mainly from the SME sector and from other organizations of enterprises, employees, researchers and experts having online access in the region would participate voluntarily and with interest at our invitation to visit our homepage and discuss future issues together. Unfortunately, this hypothesis was realized partially. Only a moderate number of young entrepreneurs or employees in the SME sector - who also consisted of university students at the Corvinus University of Budapest participated in our interactive foresight process.

\subsection{The stakeholders' scenarios}

Beyond considering the regional facilities and the changing conditions, the interactive foresight activity launched by us also involved groups of SMEs from the region to engage with the economic future of CHR. Based on the thoughts emerging in the entrepreneurship of 4 groups involving 17 volunteer young economists, several stakeholder scenarios were elaborated. Altogether, 16 scenarios were built, all analyzing the future possibilities of development of the region according to the same 4 different points of view. These considered the changing relationships between market environment and R\&D\&I, government regulations and economic crisis, sustainability and green R\&D\&I alternatively supported by the state, finally between the employment of vocationally highly qualified women and the tender opportunities. (See Table I)

Table 1. Possible futures of SMEs according to reactions on the changes of different environmental conditions

\begin{tabular}{|c|c|c|c|}
\hline \multirow[t]{2}{*}{ Scenarios' axes } & \multicolumn{3}{|c|}{ Scenario } \\
\hline & $\begin{array}{l}\text { Positive on both } \\
\text { axes }\end{array}$ & $\begin{array}{l}\text { Negative on both } \\
\text { axes }\end{array}$ & $\begin{array}{l}\text { Positive on one axis } \\
\text { and negative on the } \\
\text { other axis }\end{array}$ \\
\hline $\begin{array}{l}\text { Chnges in } \\
\text { competition and } \\
\text { coordination, as well } \\
\text { as in R\&D\&I }\end{array}$ & $\begin{array}{l}\text { "Hungary as a } \\
\text { paradise of the } \\
\text { entrepreneurs" } 1\end{array}$ & "Hourglass" 2 & $\begin{array}{l}\text { "SMEs on the waves of } \\
\text { the multinationals" } 3 \\
\text { and "Grasshopper" } 4\end{array}$ \\
\hline $\begin{array}{l}\text { Changes in } \\
\text { government } \\
\text { regulations and } \\
\text { environment, as well } \\
\text { as of the economic } \\
\text { crisis }\end{array}$ & $\begin{array}{l}\text { "The revive of } \\
\text { SMEs" } 5\end{array}$ & "Phantom Menace" 6 & $\begin{array}{l}\text { "Stamping SMEs" } 7 \text { and } \\
\text { "Vegetating, decay" } 8\end{array}$ \\
\hline
\end{tabular}




\begin{tabular}{|l|l|l|l|}
\hline $\begin{array}{l}\text { Changes in the } \\
\text { protection of the } \\
\text { environment and } \\
\text { sustainability, as well } \\
\text { as of R\&D\&I } \\
\text { governmental } \\
\text { subsidy }\end{array}$ & "Green way" 9 & & $\begin{array}{l}\text { "Green island"11 and } \\
\text { "Eye-shade" 12 }\end{array}$ \\
\hline $\begin{array}{l}\text { Changes in women } \\
\text { employment and } \\
\text { demand for tenders }\end{array}$ & "Brave hero"13 & "Dead soldier" 14 & $\begin{array}{l}\text { "Resourceful mercurial" } \\
15 \text { and "Lopsided } \\
\text { valiant" 16 }\end{array}$ \\
\hline
\end{tabular}

Source: self-made

The scenario groups encompassed the wide range of possibilities of the CHR's futures by dealing with the continuation of the present-day crisis and the lack of future perspective, innovation based on international expansion, qualified employment as well as the relationship of the multinationals and the SMEs. Only one part of the scenario groups counted with the possibility that the region might turn into knowledge economy and strengthen its competitiveness. (See scenarios 1, 2 and 3 in Table I). The second part of scenarios considered the local, qualified employment and entrepreneur-friendly government regulations as livable future. (See scenarios 5 and 7 in Table I). The third part of the scenarios regarded the turning of the relationship of the multinationals and the SMEs to a fruitful one as a key question in the CHR (see scenarios 3 and 4 in Table I).

Among the scenario-building stakeholder groups, two characteristic groups were formed, visioning the region's futures from the point of view of two special subfields. These stakeholder groups were the ones that saw business opportunities in the fields of environmental protection and sustainability (see scenarios 9 and 11 in Table I), as well as the highly qualified women employment in SMEs and of their entrepreneur behaviour (see scenarios 13 and 15 in Table I). The rest of scenarios gave the images of bankruptcy or stagnation for different reasons (see scenarios 2, 6, 10. 14 and 8, 12 and 16 in Table I).

\subsection{Scenarios concerning CHR and their relationship to the "Hungary 2025" social scenarios}

As we presented above, different stakeholder scenarios were formed along different assumptions. Achieving face-to-face workshops and online discussion about stakeholders' scenarios and their comparative analyses, new and reformed assumptions that were deeply involved in most scenarios were found. Such assumptions were continuation of the present crisis, opportunity of innovation based on expansion, focusing on qualified employment and the relationship between the multinationals and the SMEs. The futurist group has considered these assumptions important because they all illustrated visible and sensible problems - the comments of our homepage also dealt with these problems - or they react to the regional potentials that are abundantly provided by the CHR. (The futurist group consisted of the authors of this paper.) Furthermore, the only expert study known to us that was made in 2004 and dealt with the future of the economy of the CHR and outlined a concept for a regional development based on innovation, in which the CHR would also be the integrator of the domestic R\&D\&I (CHIC, 2004). This study, however, outlined this only possible, desirable (and considered at the time of preparing also feasible) future, and did not gauge the economic 
crisis. Apparently, in 2004, nobody foresaw the crisis; furthermore, Hungary joined the EU int hat year, and this fact suggested potimistic expectations.

Analyzing the information gathered on our Web site the futurist group has concluded that the participants of the online jigsaw puzzle considered different alternative futures for pursuing successful entrepreneurship. Participants' patterns of entrepreneurship visions could be divided into three alternative clusters. The "growth" alternative counted on investment fuelled by the innovation process partially supported by governmental regulations and involvement. The "freelancer" alternative covered the opportunities of individual entrepreneurship and the work-at-home scheme, where innovation was also possible if it was profitable. The "know-how" alternative focused on the marketable expertise that served the efficiency in the SME in the first place and the innovation in the second. On one hand, all three alternatives indicated that participants in the puzzle game did not consider innovation as an important characteristic of well-functioning venture, on the other hand, successful SME on the market without vocational expertise was unbelievable. Although the degree of participants' future-orientation[7] was moderate, that improved during the learning phase of the puzzle game at a statistically significant extent but at a very low measure. Opinions clearly indicated that the entrepreneur and the quality of the skilled labour as well as the employment would be the key factors of the future of the SMEs.

According to the answers to the online future-orientation survey, the increase in domestic demand, qualified available employees, transparent legal regulations, continuous R\&D\&I activity, end-of-the-world economic crisis as well as availability of credits were held to be the most important for the improvement of SMEs' competitiveness in the CHR. The viewpoints of the future venture flexibility and raising profits at the SMEs are regarded as the most important. Sadly, none of the respondents chose continuous technological renewal or innovation in this place. Furthermore, the renewing forms for using skilled labors and new organizational solutions were not considered as part of innovation.

The respondents treated their future-shaping activities realizing in the near future in very different ways. Most of them mentioned cooperation, acquirement of new markets, setting up new venture goals and development of marketing activities. Adversely, introducing new technology or innovation, extending tender activities, environment-conscious production and product development were infrequently mentioned. Of the respondents, 30 per cent had no fear about the future of their venture. Most of them, however, had fear - mostly about the financial crisis and instability as well as losing market share and being outperformed by competitors. Some mentioned workforce-drain, political conflicts of interior affairs and further strengthening of the multinationals.

Altogether from the responses of the SMEs in the CHR it was concluded that not even the respondent SMEs thought really in a future-orientated way. Although they had a concept about how a future-orientated venture should look like, still they managed to mostly follow this in everyday practice. Their fears were founded this way[8]. The small number of respondents lets us imply that an overwhelming part of the SMEs in the CHR was under future shock and operate without a vision about the future.

The scenarios that mostly matched the viewpoint of the present crisis and the lack of future perspective were the ones that represented project stagnation or decline of the SMEs for some reasons. Scenarios that for some reasons or circumstances assumed or relied on the basis of R\&D of the CHR favored innovation. The aspect of qualified employment was 
present in scenarios that where discovering and exploiting opportunities as well as regional SME futures of creativity were projected. The aspect of the relationship between the multinationals and the SMEs was mirrored in the scenarios assuming cooperation, competition or a mixture of both in this relation. Taking into account the CHIC study, the jigsaw puzzle and the survey, the scenarios were reconsidered in face-to-face workshops of all participants from the four aspects can be categorized in the following manner (see Table II).

Table 2.: Categorization of stakeholders' scenarios

\begin{tabular}{|c|c|c|c|}
\hline $\begin{array}{l}\text { Continuation of } \\
\text { present crisis and } \\
\text { lack of future } \\
\text { perspective }\end{array}$ & $\begin{array}{l}\text { Innovation based } \\
\text { international } \\
\text { expansion }\end{array}$ & $\begin{array}{l}\text { Relying on qualified } \\
\text { employment }\end{array}$ & $\begin{array}{l}\text { Relationship between } \\
\text { the multinationals } \\
\text { and SMEs }\end{array}$ \\
\hline "Dark pitfall" 10 & $\begin{array}{l}\text { "The revive of } \\
\text { SMEs" } 5\end{array}$ & $\begin{array}{l}\text { "The revive of SMEs" } \\
5\end{array}$ & $\begin{array}{l}\text { "SMEs on the waves of } \\
\text { the multinationals" } 3\end{array}$ \\
\hline $\begin{array}{l}\text { "Stamping SMEs' } \\
7 \text { and 'Vegetating, } \\
\text { decay" } 8\end{array}$ & $\begin{array}{l}\text { "Grasshopper" } 4 \\
\text { and "Stamping } \\
\text { SMEs" } 7\end{array}$ & $\begin{array}{l}\text { "Hungary as a } \\
\text { paradise of the } \\
\text { entrepreneurs" } 1\end{array}$ & $\begin{array}{l}\text { "Hungary as a paradise } \\
\text { of the entrepreneurs" } 1\end{array}$ \\
\hline „Eye-shade” 12 & "Green way" 9 & "Brave hero" 13 & $\begin{array}{l}\text { "Grasshopper" } 4 \text { and } \\
\text { "Stamping SMEs" } 7\end{array}$ \\
\hline $\begin{array}{l}\text { "Lopsided valiant" } \\
16\end{array}$ & "Brave hero" 13 & $\begin{array}{l}\text { "Resourceful } \\
\text { mercurial" } 15\end{array}$ & $\begin{array}{l}\text { "Hourglass" } 2 \text { and } \\
\text { "Vegetating, decay" } 8\end{array}$ \\
\hline “Dead soldier" 14 & $\begin{array}{l}\text { "Resourceful } \\
\text { mercurial" } 15 \text { and } \\
\text { "Brave hero" } 13 \\
\text { and "Green way" } 9\end{array}$ & "Green way" 9 & \\
\hline \multirow[t]{2}{*}{$\begin{array}{l}\text { "Phantom } \\
\text { Menace" } 6\end{array}$} & & "Green island" 11 & \\
\hline & & $\begin{array}{l}\text { "Grasshopper" } 4 \text { and } \\
\text { "Stamping SMEs" } 7\end{array}$ & \\
\hline
\end{tabular}

Source: self-made

It can be seen that the most -7 - of the stakeholder's scenarios were arranged under the point of "Depending on the skilled manpower". The second most frequent among our analyzing points of scenarios was the "Continuation of the crisis and the lack of future perspective" with six scenarios. The relationships between multinationals and the SMEs were mentioned in four scenarios. The futurist group made two axes for integrating the 16 scenarios of participant groups, paying attention to the lessons of the retro-analyses, the concepts of the stakeholders and the results and lessons of online analysis. The futurist group's scenarios were built up in the dependence of economic crisis and the usage of skilled employees (intellectual capacity).

In the scenario "Prosperity and development", it is presumed that the SMEs and the research centers of the region build up business cooperation on the territory of R\&D\&I\&Vt (where $\mathrm{Vt}=$ vocational training), for they come out from the crisis. The vocational training joined the R\&

D\&I will be the field which can assure the enterprising human resources suitable for the market economy. In the scenario of "Mutually advantageous collaboration", a more severe cooperation of the SMEs and the multinationals in the region can be realized and made mutually advantageous. In line with such assumptions, no larger change in the exploitation 
of the intellectual capacity can be expected because the R\&D capacities will not get essential assistance from the entrepreneurs, but the high-level vocational training can be supported well by R\&D capacities as they did earlier. In the third scenario "Trial of the independent national usage of intellectual capacity", the supposition is that the crisis will be long lasting and the highly educated manpower will try to use her/his intellectual power in their own private enterprises or in other SMEs. Because the SMEs remain small, a lot of forced privatized and dying enterprises will exist, a lot of them will ruin in the rigorous market, and therefore they cannot choose differently, than opting away from the region. In the fourth scenario "Lack of future perspective and Escape", a circumspect study of opportunity is presented where it is supported that the economic and debt crises go into a chronic crisis. Due to the chronic crisis, the region (and the country as well) will lose its intellectual and researching capacities and become a field of fighting with hopelessness in the EU.

It is reasonable to compare the economic scenarios of SMEs of CHR and social scenarios of the "Hungary 2025" research project (Nováky, 2010a) because the relation between the two-type groups of stakeholders can represent the relation of the part and the whole.

Besides, they constitute the wider environment in which the SMEs of CHR will work. The

future interpretation of the different points of their lives, i.e. the entrepreneur and employee attitudes of the young people living, learning, entrepreneur and working in CHR and on the other side, the attitudes of young vocational intelligence who are striving into the SMEs sector that can join each other in alternative pairs.

In research project "Hungary 2025", four scenarios were formed. "Individuals in the community network": based on the attitudes of the youth striving to amalgamation of common values, prosperity and development and they can happen to important favorable changes in Hungary, according to the scenario 1. "Society of individualists": the individualist youth concentrating on individual values and interests can make a selfish but from the point of the development of the society more or less favorable society according to the scenario 2. "Society of individuals left behind" based on the youth who are terrified of the future and another part of them who do not find their place. Their fears and bizarre reactions can be increased by the overwhelming rule of the multinationals. In this situation, the native societies will not get important roles, will not have opportunities and/or power to enforce their own interests. These possibilities are drawn in scenario 3. "Drifting and wallowing together": in scenario 4, the possibility is drafted what kind of Hungary will come to pass, if in that the aimlessness, drift and idling might dominate.

"The prosperity and development" of SMEs in CHR and the "Individuals in the community network" mutually strengthen each other. The scenarios "Lack of future perspective and Escape" in CHR and "Society of individuals left behind" can strengthen each other in their negativity. The paired evaluation of the other two scenarios is not so unambiguous. The "Mutually advantageous collaboration" and the "Society of individualists" scenarios can exist together, but they cannot assure development, social well-being and economic prosperity for the whole country for long time, even if they collaborate with each other, but the dying of CHR can become a long standing process. Going into the critical condition of the CHR can become one of the chronic inhibiting factors of the rising and also the going to a new course of the country. The "Trial of the independent national usage of the mental capacity" and the "Drifting and wallowing 
together" scenarios are also problematic, if only a few persons will feel the force to break off. The drawing-down effect of the social surrounding can strengthen the setbacks of the breakers in the CHR.

According to the results of our studies, the futures of the CHR and SMEs depend in a great measure on the social surrounding, human intelligence and mentality; however, they can also be changed, improved and damaged. We think that the future orientation of the entrepreneurs and other stakeholders of society must be strengthened to go out of the crisis and for better life-courses in CHR as well as in the whole country.

We have not got unambiguously positive answers from the stakeholders in the evaluation of the importance of innovation. The stakeholders did not think that innovation was a wonder weapon in the respect of recovery from the crisis and of the business success. They saw innovation as only one of the very important and existing factors of business success. They meant the business usage of qualification that was more important than innovation. We think that these points of view have two possible causes. First may be that the stakeholders are not future-oriented enough, so they can accept as effective only for the continuous economic results. The second may be that they believe that innovation takes place only in the long-developed products and technologies, so they do not evaluate the new modes of the working process and their usage for fitting to the business requirements and the qualification level as innovation. So the mild, social innovations are not counted to be real innovation.

\section{Conclusion and discussion}

This foresight exercise has proven that multiple interactivity can be built up into the integral foresight activity and sustained during its whole process. The online presence can automatically ensure to continue or restart the foresight activity at any time. The suitably constructed jigsaw puzzle can make quantitatively measurable the participants' learning process. Unfortunately, amid circumstances, the majority of potential stakeholders could not overcome its fears of the present and the future and remained passive and did not take part in the foresight exercise. At the average level of future orientation, the active participants could shape alternative futures of CHR and dialogue and evaluate them. The futurists could build participants' alternative futures for CHR into the "Hungary - 2025" social scenarios. It presents that the regional/meso and the national/macro levels of possible futures can be interconnected in an integral foresight exercise.

Although we know that the first results of our interactive foresight are based only on one type of stakeholder groups, thus they shall not be extended to the whole economy of CHR, nevertheless we think that it is reasonable to make known and to spread our foresight experience for the SMEs for the regional institutions, the large enterprises, R\&D organizations of the region and for various professional groups, etc. Our interactive foresight represents a new social technology in the studying of the future; therefore getting acquainted with it and its application in different fields will help in the control and the further development of this foresight process. The practical results of the foresight exercise was the acquaintance of the thoughts about possible futures of CHR may raise the interest of practical professionals, other stakeholders and decision makers in the region and the interested lay people, furthermore, may strengthen their future orientation or help them to win over their thinking with future shock. To help these, we want to make our research Web site further operate and we wait for the reflections, the critics and the proposals for the 
further developments and the joining of newer stakeholders from CHR to make our foresight activity continuous.

We consider our process and our research Web site developed in particular in the aspect of the training for the field of practical futures studies, as the students of universities and collegues can participate in developing and using of the modern and innovative foresight methods and processes, and after graduating, they can share their knowledge and experience or apply it competently in their work.

\section{Notes}

1. On the Wikipedia "Social innovation refers to new strategies, concepts, ideas and organizations that meet social needs of all kinds - from working conditions and education to communitydevelopment and health - and that extend and strengthen civil society". (http://en.wikipedia.org/wiki/Social_innovation)

2. Definition of Living Labs developed in a research project and used widely in the European Union: "Living Labs are open innovation environments in real-life settings, in which user-driven innovation is fully integrated within the co-creation process of new services, products and societal infrastructures" (European Commission Information Society and Media, 2009, p. 5). Living Labs serve to bridge the gap between the innovation and the technological development. They promote to integrate complement competences of SME and to minimize the risk of R\&D\&I process (Santoro and Conte, 2010).

3. The online jigsaw puzzle is a hybrid created by crossing between the mind map and the futures wheel. The mind map is a diagram that connects words, thoughts and tasks around a central notion (Buzan, 1996). The futures wheel is one organized way of thinking about the future that maps the possible consequences of a vision (Glenn, 2009). Our jigsaw puzzle is a modified futures wheel that follows a reverse logic: it places the elements of a vision into one mind map. Participants during the game create a mind map that gets later processed and analyzed. In the jigsaw puzzle, the following notions can be placed on knowledge society, production, employment, health, financing, competences, innovation, cooperation, state. These notions were picked through an expert approach based on the personal experience of the members of the research group. Having placed the nine notions, a filled puzzle strengthens six edges on the graph of notions consisting of three 4. In the 1990s, we prepared the first social foresight in Hungary which concerned the futures of national education and vocational training activity (Hideg and Nováky, 1998 and Hideg et al., 2013). In this program, the response rates were between 30 and 50 per cent. At the end of 1990s, we surveyed the future orientation of big firms and SMEs, whereas the response rates were 30 and 10 per cent. Jannek and Burmeister from Germany reported that the response rate was only 11.5 percent surveying on the foresight activities of ESMs in 2007 (Jannek and Burmeister, 2007). Rader mentioned that the response rate in FISTERA program was around 10 per cent (Rader, 2011). Above them only an article about a Turkish regional foresight mentioned considerable passivity of stakeholders (Özkaynak and Rodrígez-Labajos, 2010).

5. As far as we know, interactive and online foresight is being carried out in the framework of the Millennium Project (The Millennium Project's homepage available at: www.unmillenniumproject.org). Therefore, experts and futurists take part mainly in, there is no task to maintain the continuous interest and participation. Besides the Millennium Project, we also studied the homepage of the National Foresight Network (The National Foresight Network's homepage available at www.sitra.fi/en/projects/national-foresight-network) and the European Foresight Platform (EFP) (EFP's homepage available at: www.foresight-platform.eu/).

6. As voluntary scientific specialists and experts have not yet participated in our foresight, the futurists have represented the scientific knowledge about the CHR in this phase of this project.

7. The participants' future orientation was measured by an index that is a ratio between the sums of edge ratios concerning the cyclic components and the total sum of edge ratios concerning the cyclic and non-cyclic components gained from the processing of jigsaw puzzle. The future orientation index (FOI) shows the average measure of placing individual alternatives into the system of complex future alternatives of SMEs. The FOI was 44.9 and 45.5 per cent on the second round. The cause of why the change in FOI was very moderate might be that the participant students had chosen the course of Futures Studies voluntarily so they had also been interested in the future earlier.

8. Our survey results and experience are consonant with the consequences derived from macro data-based entrepreneur index analysis made by Szerb and Ács (Szerb and Acs, 2010). According to the Global Entrepreneur Index (GEI) created to measure simultaneously entrepreneur attitude, activity and aspiration inland ventures had unfavourable attitudes compared to their performance in GDP per capita. Hungary had a value as low as 0.30 in 2010 . 
The research program was carried out in the framework of "TÁMOP-4.2.1/B-09/1/KMR2010-0005" project at the Futures Studies Department of Corvinus University of Budapest.

\section{References}

Bezold, C. (2008), “Anticipatory democracy revised”, in Mannermaa, M., Dator, J. and Tiihonen, P. (Eds), Democracy and Futures, Committee for Futures, Parliament of Finland, pp. 38-51.

Buzan, T. (1996), The Mind Map Book, Penguin Books, London.

Chesbrough, H. (2003), Open Innovation: The New Imperative for Creating and Profiting

from Technology, Harvard Business School Press, Boston, MA.

CHIC (2004), A Közép-Magyarországi Régió Innovációs Stratégiája és Akcióterve

(Innovation Strategy and Action Plan for the Central Hungarian Region), CHIC Közép-

Magyarországi Innovációs Kht., Budaörs.

Da Costa, O., Wamke, P., Scapolo, F. and Cagnin, C. (2008), "The impact of foresight on policy making: insights from the FOR-LEARN mutual learning process", Technology Analysis and Strategic Management, Vol. 20 No. 3, pp. 369-387.

Daheim, C. and Uerz, G. (2006), "Corporate foresight in Europe: ready for the next step?" in 2nd International Seville Seminar on Future-Oriented Technology Analysis, Seville, September, available at: http://forea.jrc/fta/intro.html (accessed 13 October 2007).

Eriksson, A. and Weber, M. (2008), "Adaptive foresight: navigating the complex landscape of policy strategies", Technological Forecasting and Social Change, Vol. 75 No. 4, pp. 462-482. European Commission Information Society and Media (2009), Living Labs for User-Driven Innovation, Office for Official Publications of the European Communities, Luxembourg, available at:

http://ec.europa.eu/information_society/activities/livinglabs/docs/brochure_jan09_en.pdf (accessed 25 January 2010).

European Foresight Monitoring Network (2011), available at: www.foresightnetwork.eu/ index.php?option_com_content\&task_view@id_138@Itemid_52 (accessed 20 January 2013). Fuller, T. and Loogma, K. (2009), "Constructing futures; a social constructionist perspective on foresight methodology", Futures, Vol. 41 No. 2, pp. 71-79.

Georghiou, L. (2001), "Third generation foresight: integrating the socio-economic dimension", in Technology Foresight - the Approach to and Potential for New Technology Foresight Conference Proceedings, NISTEP, available at: www.nistep.go.jp/achiev/ftx/eng/mat077e/html/mat077oe.html (accessed 4 February 2013). Glenn, J. (2009), "The futures wheel", in Glenn, J. and Gordon, T.J. (Eds), Futures Research Methodology Version 3.0, The Millennium Project, CD-ROM, Washington, DC, available at: www.unmillenniumproject.org Grunwald, A. (2011), "Parliamentary technology assessment as part of technology governance", in Banse, G., Grunwald, A., Hronszky, I. and Nelson, G. (Eds), On Prospective Technology Studies, KIT Scientific Reports 7599, Karlsruhe Institute of Technology, KIZ Scientific Publishing, Karlsruhe, pp. 29-38.

Havas, A. (2011), "Governing policy process and foresight. Potencial contributions and inherent tensions", in Banse, G., Grunwald, A., Hronszky, I. and Nelson, G. (Eds), On Prospective Technology

Studies, KIT scientific reports 7599, Karlsruhe Institute of Technology, KIZ Scientific Publishing, Karlsruhe, pp. 1-18.

Havas, A., Schartinger, D. and Weber, M. (2010), "The impact of foresight on innovation policy-making: recent experiences and future perspectives", Research Evaluation, Vol. 19 No. 2, pp. 91-104. 
Hideg, É. (2007), “Theory and practice in the field of foresight”, Foresight, Vol. 9 No. 6, pp. 36-46.

Hideg, É. (2009), “Interactivity and the development of futures studies”, in Hideg, É. (Ed), Futures Studies in the Interactive Society, Futures Studies Department, Corvinus University of Budapest, Budapest, pp. 13-53, available at: http://unipub.lib.uni-corvinus.hu/398/ or http://real.mtak.hu/2118/ (accessed 5 January 2010).

Hideg, É. (2013), "Integral futures based on paradigm approach", Futures, Vol. 45 No. 1, pp. 6-15.

Hideg, É. and Nováky, E. (1998), Szakképzés és jövo"(Vocational Training and Future), Aula Kiadó, Budapest.

Hideg, É. and Nováky, E. (2000), “A hazai szolgáltató vállalatok/vállalkozások jövo"orientáltsága (Future Orientation of National Service Firms/Enterprises)”, Jövo"tanulmányok 16, Budapesti Corvinus Egyetem, Budapest.

Hideg, É, Nováky, E. and Kristóf, T. (2013), "Hungarian educational foresight: 'Vocational Training and Future"”, in Borch, K., Dingli, S. and Jørgensen, M.S. (Eds), Participation and Interaction in Foresight,Dialogue, Dissemination and Visions, Edward Elgar Publishing, Northampton, MA, pp. 223-237.

Hines, A. and Bishop, P. (2006), "Thinking about the Future, Guidelines for Strategic Foresight”, Social Technologies, Limited Liability Company (LLC), Washington, DC. Hippel, E. (2005), Democratizing Innovation.

Hronszky, I. and Fésüs, É. (2011), "Toward innovation of innovation, by Taking European Knowledge Society Seriously”, in Banse, G., Grunwald, A., Hronszky, I. and Nelson, G. (Eds), On Prospective Technology Studies, G. KIT scientific reports 7599, Karlsruhe Institute of Technology, KIZ Scientific Publishing, Karlsruhe, pp. 245-277.

Inayatullah, S. (2006), "Anticipatory action learning: theory and practice", Futures, Vol. 38 No. 6, pp. 656-666.

Jannek, K. and Burmeister, K., (2007), "Corporate foresight in small and medium-sized enterprises", The European Foresight Monitoring Network, Foresight Brief No. 101, available at: http://ec.europa.eu/research/social-sciences/pdf/efmn_2007_en.pdf (accessed 4 February 2013).

Kok, K., Rothman, D.R. and Patel, M. (2006), "Multi-scale narratives from an IA perspective: part I. and II, European and Mediterranean scenario development", Futures, Vol. 38 No. 3, pp. 261-284.

Leydesdorff, L. (2001), A Sociological Theory of Communication, The Self-Organization of the Knowledge-Based Society, Universal Publishers, available at: http://u.PUBLISH.com (accessed 12 September 2010).

Miles, I. (2008), "From futures to foresight" in Georghiou, L, Harper, J.C., Keenan, M, Miles, I. and Popper, R. (Eds), The Handbook of Technology Foresight: Concepts and Practice, Edward Elgar Publishing, Northampton, MA, pp. 24-43.

Miller, R. (2007), "Futures literacy: a hybrid strategic scenario method", Futures, Vol. 39 No. 4, pp. 341-362.

Nováky, E. (2010a), "Alternative scenarios for Hungary for the Year 2025”, Society and Economy, Vol. 32 No. 1, pp. 147-164.

Nováky, E. (Ed), (2010b), Magyarország 2025 (Hungary 2025), Gazdasági és Szociális Tanács, Budapest.

Nováky, E. (2011), “A participatív módszerek az interaktív jövo”kutatásban (Participatory Methods in the Interactive Futures Studies)", in Jövo"elméletek 18, Budapesti Corvinus Egyetem, Budapest.

Özkaynak, B. and Rodríguez-Labajos, B. (2010), "Multi-scale interaction in local scenariobuilding: a methodological framework", Futures, Vol. 42 No. 9, pp. 995-1006. 
Popper, R. (2008), "How are foresight methods selected?", Foresight, Vol. 10 No. 6, pp. 6289.

Rader, M. (2011), "Prospective technology analysis for EU level governance of research and technological development. Challenges, problems and possible solutions", in Banse, G., Grunwald, A., Hronszky, I. and Nelson, G. (Eds), On Prospective Technology Studies, KIT Scientific Reports 7599, Karlsruhe Institute of Technology, KIZ Scientific Publishing, Karlsruhe, pp. 167-176.

Santoro, R. and Conte, M. (2010), Living Labs in Open Innovation Functional Regions, ESoCE-Net, White paper, available at:

www.esoce.net/Living\%20Labs\%20in\%20Functional\%20Regions\%20-

\%20White\%20Paper.pdf (accessed 22 January 2011).

Saritas, O. (2011), Systemic Foresight Methodology, paper presented at the Forth

International Seville Conference on Future-Oriented Technology Analysis (FTA) FTA and Grand Societal Challenges - Shaping and Driving Structural and Systemic Transformations, Seville, 12-13 May 2011, p. 34, available at:

www.inovita.org/docs/1328291461Ozcan\%20Saritas_Inovita\%20

Presentation_111228.pdf (accessed 23 May 2013).

Slaughter, R. (1995), The Foresight Principle, Adamantine Press, London.

Slaughter, R. (2004), Futures Beyond Dystopia: Creating Social Foresight, Routledge, London.

Slaughter, R. (2008), “What difference does 'integral' make?”, Futures, Vol. 40 No. 2, pp. 120-137.

Statisztikai tükör (Statistical mirror) (2009), "Vol. III, KSH, Budapest, p", 109, available at: http://portal.ksh.hu/pls/ksh/docs/hun/xftp/stattukor/kkv.pdf (accessed 15 February 2011).

Stevenson, T. (2006), "From vision to action", Futures, Vol. 38 No. 1, pp. 667-672.

Szerb, L. and Acs, Z.J. (2010), "Vállalkozási tevékenység a világban és Magyarországon a Globális Vállalkozói Index (GEI) alapján (Enterprising Activity in the World and in Hungary on the Basis of Global Enterprise Index)", Magyar Tudomány, Vol. 171 No. 10, pp. 12381251 .

Toffler, A. (1970), Future Shock, Bantam Books, New York, NY.

\section{Further reading}

Nováky, E. and Hideg, É. (1998), “A hazai nagyvállalatok jövo"orientáltsága (Future Orientation of National Big Firms)", Jövo"tanulmányok 15, Budapesti Corvinus Egyetem, Budapest. 